\title{
Efek Perubahan Struktur Pati Singkong Yang Dilakukan Pretreatment Dengan Larutan Ion Dan Gelombang Mikro Terhadap Produksi Gula
}

\author{
Irfan Aruana, Hanny F. Sangiana*, Adey Tanaumaa* \\ aJurusan Fisika, FMIPA, Unsrat, Manado \\ KATA KUNCI \\ A B S T R A K
}

Pati singkong, pretreatment, karakterisasi, hidrolisis
Penelitian ini bertujuan untuk menganalisis hubungan perubahan struktur pati singkong terhadap produksi gula sebelum dan sesudah pretreatment gelombang mikro dan larutan ion. Pretreatment gelombang mikro dilakukan dengan meradiasikan gelombang elektromagnetik daya tertentu dengan tiga durasi yang berbedat pada substrat. Pretreatment larutan ion dilakukan dengan merendam substrat dalam larutan ion dengan dua konsentrasi garam selama empat hari dan kemudian dibandingkan dengan non-pretreatment. Substrat dikarakterisasi dengan XRD, FTIR dan SEM untuk menganalisis perubahan strukturnya. Produksi. Hasil karakterisasi menunjukkan bahwa struktur kristal pati menjadi lebih amorf dan ikatan antar molekulnya semakin lemah setelah dilakukan pretreatment. Morfologi permukaan bahan menjadi lebih kasar setelah terpapar radiasi microwave. Disisi lain, jumlah fiber pada substrat semakin berkurang setetelah direndam dalam larutan ion. Ketika substrat dihidrolisis, kandungan gula yang didapatkan lebih tinggi daripada tanpa pretreatment.
KEYWOR D S

Cassava starch, pretreatment, characterization, hydrolysis

\begin{abstract}
A B S T R A C T
This research aims to analyze the correlation of the structural change on sugar production of cassava starch before and after microwave and ionic liquid pretreatments. A microwave pretreatment was carried out by radiating electromagnetic wave with fixed power with three different durations on the substrate. The ionic liquid pretreatment was conducted by soaking the substrate in to saline water with two salt concentrations for four days and the results were compared to non-pretreatment. Then, the substrates were measured by XRD, FTIR and SEM to analiyze the structural changes. The characterization result showed that the starch crystal structure became more amorphous and molecules bonds were weaker after pretreatment. The surface morphology was rougher after being radiated by microwave. On the other hand, the fiber contents of substrate decreased after soaked on ionic liquid. When substrate were hidrolized, the sugar obtained were higher than without pretreatment.
\end{abstract}

TERSEDIA ONLINE 01 Februari 2018

\section{Pendahuluan}

Singkong (Manihot esculenta) adalah tanaman sumber energi tinggi yang pemanfaatannya sangat beragam karena dapat digunakan sebagai makanan dan sumber energi dengan memanfaatkan kandungan karbohidratnya (Edhirej, 2015). Pati singkong mudah untuk diolah dan sangat berlimpah serta meningkat setiap tahunnya membuatnya menjadi salah satu pilihan sebagai bahan baku makanan maupun sumber karbohidrat terutama sumber glukosa sebagai bahan baku pembuatan bioethanol. Pada tahun 2016 produksi singkong dunia mencapai 288,4 Juta Ton (FAO, 2016), tahun 2015 produksi singkong di Indonesia mencapai

*Corresponding author: Jurusan Fisika FMIPA UNSRAT, Jl. Kampus Unsrat, Manado, Indonesia 95115; Email address: aruan.irfan13@gmail.com Published by FMIPA UNSRAT (2018) 
1.003.494 Ton dan Sulawesi Utara mencapai 3.685 Ton pada (BPS, 2015). Oleh karena itu sangat penting untuk mengetahui sifat fisika-kimia pati singkong sehingga bisa dimanfaatkan menjadi sesuatu yang lebih bernilai seperti gula sebagai bahan baku pembutan bioetanol.

Bioetanol adalah sumber energi terbarukan yang ramah lingkungan karena berasal dari biomassa dan diharapkan menjadi salah satu solusi untuk mengurangi pemanasan global serta mengatasi keterbatasan sumber energi fosil (Kumar, 2009; Sangian dkk., 2017). Pengolahan biomassa pati singkong menjadi glukosa sebagai bahan baku pembuatan bioetanol sangat cocok karena mudah dibiodegradasi (Tonoukari, 2004). Akan tetapi, proses konversi pati singkong menjadi sumber glukosa belum maksimal sehingga perlu dilakukan pretreatment atau dimodifikasi untuk meningkatkan produksinya. Biomassa pati singkong dilakukan pretreatment untuk mendapatkan hasil yang diinginkan dan untuk memenuhi persyaratan dalam pembuatannya (Olanbiwoninu, 2012; Sasue dkk., 2017). Proses pretreatment berfungsi untuk memodifikasi struktur pati serta mengubah sifat fisika-kimia pati supaya lebih mudah dikonversi menjadi glukosa (Tonoukari, 2004). Dari penelitian sebelumnya oleh Kumar (2009) dijelaskan bahwa pretreatment meningkatkan produksi gula.

Pretreatment dapat dilakukan dengan menggunakan larutan ion yaitu air garam dan gelombang mikro. Kelebihan dari gelombang mikro adalah pemanasan berlangsung sangat cepat dan dapat meningkatkan hasil reaksi (Kappe, 2004). Sedangkan kelebihan larutan ion (air garam) adalah bahannya mudah dicari, tidak menghasilkan zat kimia, tidak mahal dan limbahnya tidak berbahaya (Adams et al., 2004). Pretreatment menggunakan radiasi gelombang mikro terbukti berkontribusi dalam meningkatkan hasil reaksi (Lewicka, 2015). Pada penelitian sebelumnya dilaporkan bahwa pretreatment menggunakan larutan ion menyebabkan terputusnya ikatan hidrogen pada pada selulosa (Feng, 2008). Lappainen (2015) juga pernah melakukan pretreatment menggunakan larutan ion dan gelombang mikro terhadap kentang, beras dan jagung mengakibatkan reaksi lebih cepat serta meningkatkan hasil reaksi. Pada penelitian Pangau et al. (2017) dijelaskan bahwa pretreatment menggunakan gelombang mikro terhadap biomassa kayu cempaka menurunkan tingkat kristalinitasnya.

Penelitian ini dilakukan untuk menganalisis efek perubahan struktur kristal pati singkong sebelum dan sesudah pretreatment larutan ion dan gelombang mikro terhadap produksi gula. Pretreatment larutan ion dilakukan dengan merendam pati dalam larutan ion sedangkan pretreatment gelombang mikro dilakukan dengan meradiasikan gelombang mikro kedalam pati (Lappainen, 2015). Proses konversi pati menjadi gula dilakukan dengan hidrolisis (Kumar, 2009). Perubahan struktur pati seperti kristal, gugus fungsi dan morfologi diukur menggunakan X-Ray
Diffraction, Fourier Transform Infra-Red dan Scanning Electrom Microscope. Hasil karakterisasi dan hidrolisis dianalisis untuk mengetahui hubungan perubahan struktur pati terhadap produksi gula.

\section{Material dan Metode \\ Alat dan Bahan yang Digunakan}

Bahan-bahan yang dipakai adalah singkong sebagai bahan utama, garam dan air laut digunakan untuk mengionisasi pati singkong (pretreatment larutan ion), enzim amilase digunakan untuk energi aktivasi pada saat hidrolisis, air digunakan sebagai pelarut (Sangian dkk.,2016). Alat untuk proses pembuatan tepung singkong adalah penggiling dan untuk penjemuran tepung digunakan wadah plastik. Pretreatment gelombang mikro menggunakan Oven (SHARP R-728W-IN), proses hidrolisis menggunakan gelas ukur untuk mengukur volum larutan dan sebagai tempat untuk melakukan hidrolisis, heater sebagai pemanas, magnet untuk mengaduk, refraktometer (ATAGO ATC-1 Japan) untuk mengukur persentasi gula dalam larutan, termometer untuk mengukur suhu dari larutan, stopwatch untuk mengukur waktu serta neraca untuk menghitung massa larutan.

\section{Pretreatment Larutan lon}

Tepung singkong ditimbang masing-masing sebanyak $50 \mathrm{~g}$ dan direndam dengan larutan ion dengan dua kadar garam berbeda pada wadah tertutup selama empat hari, kemudian dinetralkan dengan air untuk mengurangi larutan ion yang terdapat pada pati kemudian dikeringkan. Hasilnya adalah pati yang sudah termodifikasi yang sudah kering atau disebut substrat.

\section{Pretreatment Gelombang Mikro}

Pati sebanyak $50 \mathrm{~g}$ dimasukkan kedalam tungku microwave oven dan dipanggang dengan daya tertentu dengan tiga durasi yang berbeda menggunakan gelombang mikro dan menghasilkan pati yang termodifikasi gelombang mikro.

\section{Hidrolisis}

Substrat sebanyak 20 g dimasukkan kedalam gelas ukur yang berisi air $180 \mathrm{~g}$ dan mencampurnya dengan enzim amilase sebanyak $1 \mathrm{~mm}^{3}$ sebagai aktivasi energi yang mempercepat reaksi larutan, dipanaskan dan diaduk sampai yield yang didapatkan konstan. Kandungan gula diukur menggunakan refraktometer setiap kenaikan suhu $10^{\circ} \mathrm{C}$ sampai suhu $\geq 80^{\circ} \mathrm{C}$ waktunya dicatat dan massa larutan dihitung untuk melihat peningkatan kadar dan yield gula. Kemudian suhu larutan ditahan pada $80^{\circ} \mathrm{C}-85^{\circ} \mathrm{C}$ sampai yield tidak berubah.

\footnotetext{
Karakterisasi Struktur dengan X-RD, SEM dan FT-IR

Substrat sebelum dan sesudah pretreatment dianalisis karakteristiknya dengan menggunakan XRD, FTIR dan SEM di Laboratorium Mineral dan Material Maju Universitas Negeri Malang dan hasilnya dianalisis.
} 
Struktur Kristal: Indeks kristalinitas dan ukuran Kristal

Data yang dihasilkan setelah karakterisasi XRD berupa Intensitas, panjang gelombang yang sudah ditetapkan dan sudut difraksi. Data tersebut digunakan untuk mencari tingkat kristalinitas, derajat kristalinitas, indeks miller dan ukuran kristalnya.

Menghitung nilai indeks Miller menggunakan persamaan Bragg. Kristalinitas substrat dihitung dengan persamaan Segal (Marimuthu et al, 2013), Herman (Bansal et al, 2010), dan persamaan Soltys (Nuwamanya et al, 2009). Ukuran Kristal dihitung dengan persamaan Debye Scherrer seperti dalam laporan dari penulis Singh, (2006).

\section{Yield gula} Yield $(\%)=\frac{\text { Persentase Gula (96)xMassa total larutan(g) }}{\text { Massa pati awal }(g)}$

\section{Hasil dan Pembahasan}

\section{Hasil Karakterisasi X-Ray Diffraction}

Tingkat kristalinitas pati singkong semakin turun apabila lebih lama terpapar radiasi gelombang mikro. Pati singkong yang diberi pretreatment dengan daya tertentu dan waktu pemaparaan diperbesar, kristalinitas mempunyai tren menurun juka dibandingkan dengan non-pretreatment. Hal ini mirip yang ditunjukan pada pretreatment dengan menggunakan larutan ion.

Hasil menunjukan bahwa semakin tinggi konsentrasi garan dalam larutan ion, kristalinitas substrate juga semakin menurun dibandingkan dengan singkong tanpa pretreatment.

Penurunan kristalitas menyebabkan ukuran Kristal pati meningkat. Ini disebabkan oleh susunan atom-atom pati yang semakin tidak teratur sehingga memperbesar ukuran Kristal dan memperbanyak porositas atau ruang kosong didalamnya (Lee et al., 1997).

\section{Hasil karakterisasi Fourier Transform Infra Red}

Pati singkong yang dilakukan pretreatment menggunakan gelombang mikro dengan waktu yang lebih lama memilki transmitansi yang semakin besar. Artinya, daya serap bahan terhadap energi inframerah semakin berkurang jika semakin lama terpapar radiasi gelombang mikro. Hal ini dikarenakan ikatan antar molekul pada pati semakin lemah serta rusaknya rantai dextran yang disebabkan vibrasi oleh gelombang mikro (Xie et al, 2013).

Pati singkong yang dilakukan Pretreatment larutan ion memiliki nilai transmitansi yang lebih tinggi dibandingkan tanpa pretreatment. Semakin tinggi konsentrasi larutan ion yang digunakan maka semakin besar nilai transmitansinya artinya ikatan antar molekul pada pati singkong semakin lemah akibat adanya pengaruh dari anion dan kation terhadap atom-atom pada pati (Chen et al., 2014).
Hasil karakterisasi Scanning Electron Microscope

Perbedaan morfologi pati singkong yang dilakukan pretreatment gelombang mikro dengan daya tertentu dan tiga durasi waktu pemaparan dapat dilihat pada foto SEM. Dari analisis permukaan substrat menunjukkan bahwa radiasi gelombang mikro menyebabkan permukaan granula pati menjadi lebih kasar.

Berbeda dengan pretreatment gelombang mikro, pretreatment menggunakan larutan ion hanya dapat menghilangkan fiber tetapi permukaan granula pati tidak berubah menjadi kasar. Gambar 2 menunjukkan bahwa pada pati tanpa pretreatment masih terdapat selaput warna putih yang membungkus granula pati yang disebut fiber, tetapi setelah dilakukan pretreatment dengan larutan ion pada konsentrasi pertama jumlah fiber pada sampel menjadi berkurang bahkan hilang ketika dilakukan pretreatment dengan larutan ion dengan konsentasi yang lebih besar.

\section{Yield Gula Hasil Hidrolisis}

Hasil hidrolisis menunjukkan bahwa yield gula yang dihasilkan dengan pretreatment larutan ion dan gelombang mikro lebih banyak dibandingkan dengan tanpa pretreatment. Yield gula dari pati singkong pretreatment dengan larutan ion kadar $3,5 \%$ sebanyak $80.5 \%$ dan $10 \%$ sebanyak $92 \%$.

Yield gula dari pati singkong dengan pretreatment microwave daya $300 \mathrm{~W}$ selama 10 menit sebanyak $81.75 \%, 20$ menit sebanyak $87.75 \%$ dan 30 menit sebanyak $90.75 \%$.

\section{Hubungan perubahan kristalinitas, absorbansi dan morfologi bahan terhadap produksi gula.}

Kristalinitas pati singkong menurun akibat pretreatment larutan ion dan gelombang mikro akan tetapi menyebabkan produksi gula meningkat, hal ini mendukung penelitian (Sen et al., 2012), dimana yield gula meningkat ketika kristalinitas selulosa menurun. Apabila kristalinitas bahan menurun maka enzim lebih mudah untuk mencapai ikatan glikosidik sehingga mempermudah konversi gula (Samayam, 2010). Produksi gula pati hasil hidrolisis juga meningkat seiring menurunnya absobansi pati singkong. Penurunan daya serap 36ydrog oleh pati dikarenakan ikatan antar molekul yang semakin lemah serta putusnya ikatan 36ydrogen sehingga mempermudah proses hidrolisis (Sen et al., 2012). Dari data SEM memperlihatkan bahwa pretreatment gelombang mikro menyebabkan morfologi pati semakin kasar dan pretreatment larutan ion menghilangkan fiber akan tetapi gula hasil hidrolisis meningkat, menurut Bogdal et al. (2000) bahwa rusak atau robeknya granula pati dapat memperlancar hidrolisis. Penelitian Sen et al. (2012) juga memperlihatkan bahwa hilangnya fiber pati menyebabkan proses hidrolisis lebih mudah. 
4. Kesimpulan

a. Pretreatment larutan ion dan gelombang mikro mengubah struktur pati, meliputi:

- Pretreatment menggunakan larutan ion dan gelombang mikro menurunkan kristalinitas dan melemahkan ikatan antar molekul pati singkong.

- Pretreatment menggunakan gelombang mikro memperbesar ukuran dan memperkasar permukaan granula pati sedangkan petreatment larutan ion menghilangkan fiber pada pati.

b. Gula yang diproduksi dengan pretreatment larutan ion dan gelombang mikro lebih banyak dibanding tanpa pretreatment. Produksi gula semakin meningkat apabila semakin lama terpapar radiasi gelombang mikro ataupun kadar larutan ion yang digunakan semakin besar.

c. Kristalinitas, ikatan antar molekul dan jumlah fiber pada pati berbanding terbalik terhadap produksi gulanya.

\section{Daftar Pustaka}

Adams, D.J., P.J. Dyson, S.J. Tavener. 2004. Chemistry In Alternative Reaction Media. Wiley.

Badan Pusat Statistik (BPS). 2015. Produksi Singkong. http://www.bps.go.id/ [3Februari 2017]

Bansal, P., M. Hall, M.J. Realff, J.H. Lee, A.S. Bommarius. 2010. Multivariate Statistical Analysis of X-Ray Data From Cellulose: A New Method to Determine Degree Of Crystallinity and Predict Hydrolysis Rates. Bioresource Technology. 101: 4461- 4471.

Bogdał, D., S. Bednarz, M. Łukasiewicz. 2006. Microwave Induced Thermal Gradients in Solventless Reaction Systems. Tetrahedron. 62(40): 9440-9445.

Chen, J., K. Vongsanga, X. Wang, N. Byrne. 2014. What Happens During Natural Protein Fibre Dissolutionin Ionic Liquids. Materials. 7:6158 6168. doi:10.3390/ma7096158

Edhirej, E., S.M. Sapuan, M. Jawaid, N.I. Zahari. 2015. Cassava: Its Polymer, Fiber, Composite, and Application. Polymer Composites. (1):1-15. DOI 10.1002/pc.23614

Feng, Li, Z.L. Chen. 2008. Research Progress on Dissolution and Functional Modification of Cellulose in Ionic Liquids. Journal of Molecular Liquids. 142:1-5.

Food and Agriculture Organization. 2016. Food Outlook Biannual Report on Global Food Markets. ISSN 0251-1959.

Kappe, C.O. 2004. Controlled Microwave Heating in Modern Organic Synthesis. Review. DOI: 10.007/s 11030-009-9138-8.

Kizil, R., J. Irudayaraj, K. Seetharaman. 2002. Characterization of Irradiated Starches by Using FT-Raman and FTIR Spectroscopy. Journal of Agricultural and Food Chemistry. 50: 39123918.
Kumar, P., D.M. Barrett, M.J. Delwiche, P. Stroeve. 2009. Methods for Pretreatment of Lignocellulosic Biomass for Efficient Hydrolysis and Biofuel Production. Industrial and Engineering Chemistry Research. DOI:10.1021/ie801542g.

Lappalainen, K. 2015. Modification of Native and Waste Starch by Depolymerization and Cationization. Oulu: University of Oulu. ISBN 978 952-62-0966-1

Lee, J. 1997. Biological Conversion of Lignocellulosic Biomass to Ethanol. Journal of Biotechnology. 56: $1-24$.

Marimuthu, M., U. Sundaram, P. Gurumoorthi. 2013. X-Ray Diffraction and Starch Analysis of Nano Sized Seed Powder of Velvet Bean (Mucuna Pruriens). Indo American journal of Pharmaceutical Research. 3(6): 4319-4329.

Nurwamanya, E., Y. Baguma, N. Emmambux, P. Rubaihayo. 2010. Crystalline and pasting properties of cassava starch are influenced by its molecular properties. African Journal of Food Science. 4(1) : 008-015.

Olanbiwoninu, A.A., S.A. Odunfa. 2012. Enhancing The Production of Reducing Sugars From Cassava Peels by Pretreatment Methods. International Journal of Science and Technology. 2(9):2224-3577.

Samayam, I., and C. Schall. 2010. Saccharification of ionic liquid pre-treated biomass with commercial enzyme mixtures. Bioresource Technology. 101:3561-3566.

Sangian, H.F., G.H. Tamuntuan, H.I.R. Mosey, V. Suoth, B.H. Manialup. 2017. The Utilization of Arenga Pinnata Ethanol In Preparing One PhaseAqueous Gasohol. ARPN Journal of Engineering and Applied Sciences. 12(24):7039-7046.

Sangian, H.F., I. Aruan, R. Telleng, H.I.R. Mosey, G.H. Tamuntuan. 2016. Phase Transformation of Solid Biomass Pretreated by Ionic Solution into Liquid Sugar. International Seminar on Chemical Engineering In conjunction with Seminar Soehadi Reksowardojo; Bandung, 27-28 Oktober 2016.

Sasue, R., H.F. Sangian, H.I.R. Mosey. 2017. Analisis Pengaruh Radiasi Gelombang Mikro Pada Struktur Kristal Pati (Starch). Jurnal Mipa Unsrat Online. 6(1) 59-62.

Sen, S.M., J.B. Binder, R.T. Raines, C.T. Maravelias. 2012. Conversion of Biomass to Sugars Via Ionic Liquid Hydrolysis: Process Synthesis And Economic Evaluation. Biofuels, Bioproduct Biorefining. 6:444-452. DOI: 10.1002/bbb.1336.

Shen, H., D. Fan, L. Huang, Y. Gao, H. Lian, J. Zhao, H. Zhang. 2017. Effects of microwaves on Molecular Arrangements in Potato Starch. Royal society of chemistry. 7: $14348-14353$. DOI: 10.1039/c6 ra28048j.

Singh, V., S.Z. Ali, R. Somashekar, P.S. Mukherjee. 2006. Nature of Crystallinity in Native and Acid Modified Starches. International Journal of Food 
Properties. $\quad 9(4): 845-854$.

DOI:

10.1080/109429 10600698922.

Stuart, B. 2010. Infrared Spectroscopy: Fundamentals and Applications. Wiley, Chicester.

Tonoukari, N.J. 2004. Cassava and The Future of Starch. Elektronic Journal of Biotechnology, 7(1):1-4.

Xie, Y., M. Yan, S. Yuan, S. Sun, Q. Huo. 2013. Effect Of microwave Treatment on The Physicochemical Properties of Potato Starch Granules. Journal Chemistry Central. 7(1): 1-8. 